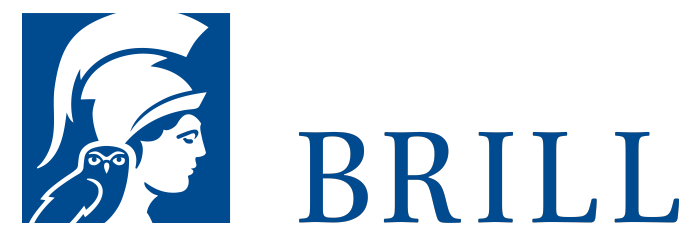

\title{
Theorizing Rituals, Volume 1 Issues, Topics, Approaches, Concepts (Paperback)
}

Authors:Jens Kreinath, J.A.M. Snoek, and Michael Stausberg

Volume one of Theorizing Rituals assembles 34 leading scholars from various countries and disciplines working within this field. The authors review main methodological and meta-theoretical problems (part I) followed by some of the classical issues (part II). Further chapters discuss main approaches to theorizing rituals (part III) and explore some key analytical concepts for theorizing rituals (part IV). The volume is provided with extensive indices.

\section{Readership}

Social anthropologists, sociologists, psychologists, theologians, and all those interested in ritual studies and the study of religion.

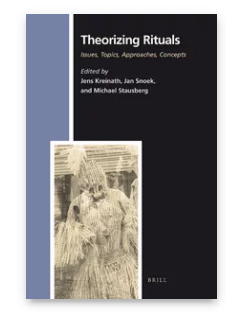

Pages: xxviii, 78o pp.

Language: English

Subjects:

History of

Religion, Religious

Studies, General, Biblical Studies

Publisher: Brill

Paperback

Publication date:

$25 \mathrm{Jul} 2008$

ISBN: 978-90-

04-17077-3

List price

USD $\$ 107.00$ 
Jens Kreinath (Dr. phil.) is affiliated to the Institute for Religious Studies at the University of Heidelberg and currently Visiting Assistant Professor of Anthropology at Wichita State University (U.S.A.). He is co-editor of The Dynamics of Changing Rituals (2004) and his publications include Semiose des Rituals (2006). His research interests focus upon theoretical and methodological issues in the anthropological study of religions. He is planning a publication on Ritual and Reflection: Tropes in Transformation and Transgression.

Jan Snoek studied in Leiden (The Netherlands). In 1996 he held the Théodore Verhaegen Chair (Freemasonry) of the Free University of Brussels (ULB). Currently he teaches Sciences of Religions at the University of Heidelberg (Germany). He published widely about the development of masonic rituals. The edited volume Women's Agency and Rituals in Mixed and Female Masonic Orders (with Alexandra Heidle) will appear with Brill this year. In preparation is a monograph Transferring Masonic Rituals from Male to Mixed and Female Orders.

Michael Stausberg (Dr. phil.) is professor of the History of Religions at the University of Bergen (Norway). His publications include Die Religion Zarathushtras (3 vols. 2002-2004). He is the editor of Zoroastrian Rituals in Context (2004). Apart from a study of the contemporary Zoroastrian priesthood in India and essays on a variety of topics (from the history of the study of religion to modern tourism), Stausberg is currently preparing a work on the terminology used in the study of religion (working title: The Vocabulary of Religious Studies).

For more information see brill.com

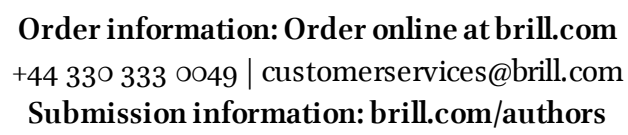

